\title{
Expression of immune response genes in peripheral blood of cattle infested with Rhipicephalus microplus
}

\author{
R. Domingues ${ }^{1,2}$, S. Wohlres-Viana ${ }^{1,3}$, D.R.L. Reis ${ }^{1}$, H.C. Teixeira ${ }^{3}$, \\ A.P. Ferreira ${ }^{3}$, S.E.F. Guimarães ${ }^{2}$, M.C.A. Prata ${ }^{1}$, J. Furlong1, \\ R.S. Verneque ${ }^{1}$ and M.A. Machado ${ }^{1}$ \\ ${ }^{1}$ Embrapa Gado de Leite, Juiz de Fora, MG, Brasil \\ ${ }^{2}$ Universidade Federal de Viçosa, Viçosa, MG, Brasil \\ ${ }^{3}$ Universidade Federal de Juiz de Fora, Juiz de Fora, MG, Brasil \\ Corresponding author: M.A. Machado \\ E-mail: marco.machado@embrapa.br
}

Genet. Mol. Res. 13 (2): 4013-4021 (2014)

Received August 19, 2013

Accepted December 16, 2013

Published May 23, 2014

DOI http://dx.doi.org/10.4238/2014.May.23.12

\begin{abstract}
The bovine tick Rhipicephalus microplus is responsible for severe economic losses in tropical cattle production. Bos indicus breeds are more resistant to tick infestations than are Bos taurus breeds, and the understanding of the physiological mechanisms involved in this difference is important for the development of new methods of parasite control. We evaluated differences in the transcript expression of genes related to the immune response in the peripheral blood of cattle previously characterized as resistant or susceptible to tick infestation. Crossbreed F2 Gir x Holstein animals (resistant, $\mathrm{N}=6$; susceptible, $N=6$ ) were artificially submitted to tick infestation. Blood samples were collected at 0,24 , and $48 \mathrm{~h}$ after tick infestation and evaluated for transcript expression of the CD25, CXCL8, CXCL10, FoxP3, interleukin (IL)-10, and tumor necrosis factor alpha (TNF $\alpha)$ genes. Gene expression of CD25 (6.00, P < 0.01), IL-10 (31.62, P < 0.01 ), FoxP3 (35.48, P $<0.01$ ), and CXCL10 (3.38, P $<0.05$ ) was
\end{abstract}


altered in the resistant group at $48 \mathrm{~h}$ compared with samples collected before infestation. In the susceptible group, CXCL8 (-2.02, P $<0.05)$ and CXCL10 $(2.20, \mathrm{P}<0.05)$ showed altered expression $24 \mathrm{~h}$ after infestation. CXCL8 $(-5.78, \mathrm{P}<0.05)$ also showed altered expression at $48 \mathrm{~h}$ after infestation when compared with samples collected before infestation. We detected a correlation between $\mathrm{T} \gamma \delta$ cell activity and the immunological mechanisms that result in a higher resistance to $R$. microplus in cattle.

Key words: Bos taurus; Bos indicus; Tick; Real-time polymerase chain reaction

\section{INTRODUCTION}

The bovine tick Rhipicephalus microplus is responsible for severe economic losses in the beef and milk industry in the tropics (Jonsson, 2006). The main economic impacts include the high costs involved in parasite control, as well as decreases in fertility, body weight, and milk production. In addition, these ectoparasites are also vectors for the hemoparasites Babesia bovis, Babesia bigemina and Anaplasma marginale, which cause tick fever (Regitano and Prayaga, 2010).

Currently, control strategies involve the use of chemical acaricides (George et al., 2004). However, due to increase acquired resistance to these products (Leite et al., 1995), chemical residues in meat and milk (Alvinerie et al., 1999), and high associated costs (Samish, 2000), alternative methods have been investigated to allow for more efficient control (Sonenshine et al., 2006). To develop these methods, it is first necessary to obtain knowledge regarding the host-parasite relationship (Reck et al., 2009).

Typically, Bos indicus animals are more resistant to ticks than are Bos taurus, although some variation occurs among and within breeds (Seifert, 1971). Genetic variations in tick resistance result from differences in a variety of mechanisms that are not fully understood, although the involvement of genes related to the immune system appears to be undeniable (Regitano and Prayaga, 2010).

Although innate immunity differences among the B. indicus and B. taurus breeds are the basis of animal parasite resistance, host resistance is considered to be a main acquired trait since the high resistance level observed in Zebu animals becomes clear only after an initial susceptible period following the primary infestation (Wagland, 1978).

Recently, gene expression studies have been used to better understand the immune response process that results in different levels of tick resistance. Most of these studies were performed using skin biopsies from the infestation site (Wang et al., 2007; Kongsuwan et al., 2008; Bagnall et al., 2009; Nascimento et al., 2010; Piper et al., 2008, 2010), and thus far, only one study has evaluated the peripheral blood gene expression in bovine (Piper et al., 2009). The lack of available samples before the artificial infestation, however, has limited understanding of the response process to the tick.

Therefore, we evaluated the expression profile of genes related to the immune response in the peripheral blood of cattle infested with the tick $R$. microplus, and compared differentially expressed genes between resistant and susceptible bovine animals in response to tick infestation. 


\section{MATERIAL AND METHODS}

\section{Experimental animals}

Animals were selected from an F2 outbreed population produced by crossing F1 animals (Gir x Holstein). Detailed information regarding this population, including breeding schemes, phenotypic evaluation, and genetic value evaluation processes, was described by Machado et al. (2010). Briefly, all animals were ranked by the predicted genetic value for tick resistance. Next, 6 animals at the resistance extreme and 6 animals at the susceptible extreme were selected for gene expression assays. All experimental and sampling procedures using the research animals were conducted in accordance with the Brazilian Ethics, Bioethics, and Animal Care Committee (CEBEA) guidelines.

\section{Infestation and blood sampling}

Selected animals were disinfested from tick natural infestations with 2 showers of non-systemic acaricide 21 and 14 days before experimental infestation. Animals were kept in a tie-stall system with a concrete floor and were scraped once a day until experimental infestation. Approximately 20,000 R. microplus tick larvae were distributed on the animals' back regions. Blood samples from all animals were collected at 3 different times, before infestation $(0 \mathrm{~h})$ and 24 and $48 \mathrm{~h}$ after infestation. Peripheral blood was collected by puncture at the caudal vein using vacuum tubes containing anticoagulant. Samples were kept at $4-8^{\circ} \mathrm{C}$ for 48 $\mathrm{h}$ to allow for cell separation by decantation. Next, buffy coats were collected and stored in microcentrifuge tubes for RNA extraction.

\section{RNA extraction and reverse transcription}

The samples were pre-purified and homogenized using the commercial kit QIAshredder (Qiagen; Hilden, Germany) according to manufacturer instructions. Total RNA extraction and purification were performed using the commercial RNeasy Mini Kit (Qiagen) according to manufacturer instructions. RNA quantification was performed in an ND-1000 spectrophotometer (NanoDrop; Wilmington, DE, USA). Total RNA integrity and the absence of genomic DNA were evaluated using the 2100 Bioanalyzer platform (Agilent Technologies; Palo Alto, CA, USA). RNA samples were stored at $-80^{\circ} \mathrm{C}$ until use.

cDNA was produced using the commercial kit SuperScript III First-Strand Synthesis SuperMix (Invitrogen; Carlsbad, CA, USA) according to manufacturer instructions, and stored at $-80^{\circ} \mathrm{C}$ until quantitative polymerase chain reaction (qPCR) was carried out.

\section{Primer sequences and amplification conditions}

The qPCR primers used to evaluate the expression of genes related to the immune response [genes encoding CD25, CXCL8, CXCL10, FoxP3, interleukin (IL)-10, and tumor necrosis factor alpha $(\mathrm{TNF} \alpha)$ ] were synthesized according to sequences found in the literature. The housekeeping genes GAPDH and HPRT were used as controls (Table 1).

For each selected gene, an optimal amplification condition (cDNA and primer concentra- 
tion) was selected to achieve a standard efficiency among all selected genes. Relative quantification was performed in duplicates using real-time PCR (Prism 7300 Sequence detection Systems; Applied Biosystems; Foster City, CA, USA). Each reaction was composed of a mixture of cDNA, specific primer sets for each reaction, $10 \mu \mathrm{L}$ iTaq SYBR Green Supermix With ROX (Bio-Rad Laboratories; Hercules, CA, USA), and nuclease-free water to a final volume of $20 \mu \mathrm{L}$. Amplification conditions consisted of $2 \mathrm{~min}$ at $50^{\circ} \mathrm{C}, 10 \mathrm{~min}$ at $95^{\circ} \mathrm{C}$, followed by 40 cycles $\left(95^{\circ} \mathrm{C}\right.$ for $15 \mathrm{~s}$ and $60^{\circ} \mathrm{C}$ for $1 \mathrm{~min}$ ). After each qPCR run, melting curve analysis was performed for each sample to confirm that a single specific product was generated. The variation coefficient (VC) was calculated between duplicates, and those presenting more than $5 \%$ variation were repeated.

\begin{tabular}{|c|c|c|c|}
\hline Gene $^{a}$ & Fragment size (bp) & Primers $\left(5^{\prime}-3^{\prime}\right)$ & Reference \\
\hline $\mathrm{CD} 25$ & 209 & $\begin{array}{l}\text { F- TGCTAAGAGCATCCCGACTT } \\
\text { R- TAGCTTGGAGGACTGGGCTA }\end{array}$ & Piper et al., 2009. \\
\hline CXCL8 & 113 & $\begin{array}{l}\text { F- CACTGTGAAAAATTCAGAAATCATTGTTA } \\
\text { R- CTTCACCAAATACCTGCACAACCTTC }\end{array}$ & Leutenegger et al., 2000. \\
\hline CXCL10 & 177 & $\begin{array}{l}\text { F- AGTGGAAGCCCCTGCAGTAAA } \\
\text { R-AGTCCCAGCCTTGCTACTGACA }\end{array}$ & Kongsuwan et al., 2008. \\
\hline FoxP3 & 74 & $\begin{array}{l}\text { F-AAGAGCCCAGGGACAACTTTC } \\
\text { R- GGGTTCAAGGAGGAAGAGGAA }\end{array}$ & Seo et al., 2007. \\
\hline IL10 & 94 & $\begin{array}{l}\text { F- CCAAGCCTTGTCGGAAATGA } \\
\text { R- GTTCACGTGCTCCTTGATGTCA }\end{array}$ & Leutenegger et al., 2000. \\
\hline TNF $\alpha$ & 103 & $\begin{array}{l}\text { F- TCTTCTCAAGCCTCAAGTAACAAGT } \\
\text { R- CCATGAGGGCATTGGCATAC }\end{array}$ & Leutenegger et al., 2000. \\
\hline GAPDH & 119 & $\begin{array}{l}\text { F- GGCGTGAACCACGAGAAGTATAA } \\
\text { R- CCCTCCACGATGCCAAAGT }\end{array}$ & Leutenegger et al., 2000. \\
\hline HPRT & 290 & $\begin{array}{l}\text { F- GCCGACCTGTTGGATTACAT } \\
\text { R- ACACTTCGAGGGGTCCTTTT }\end{array}$ & Tao et al., 2004. \\
\hline
\end{tabular}

${ }^{\mathrm{a}} \mathrm{CD} 25=$ alpha chain of the IL2 receptor (IL2R $\alpha$ ); CXCL8 = interleukin 8; IL10 = interleukin 10; TNF $\alpha=$ tumor necrosis factor alpha; GAPDH = glyceraldehyde-3-phosphate dehydrogenase; HPRT = hypoxanthine-guanine phosphoribosyltransferase.

\section{Statistical analysis}

Samples were grouped according to time after tick infestation $(0,24$, and $48 \mathrm{~h})$ and the animal's phenotypic profile (resistant or susceptible to tick infestation). Gene expression differences were evaluated by comparing susceptible and resistant animals, time after infestation, and interactions. Using this method, we evaluated the effect of infestation time and phenotype.

Relative expression analysis was performed using the REST $^{\circ} 2009$ software (Pfaffl et al., 2002). Briefly, this software calculates the expression of one group (treatment) compared with another group (control) for each gene based on the cycle threshold $\left(\mathrm{C}_{\mathrm{T}}\right)$ values, and allows for correction for the amplification efficiency of each gene. In addition, because we used 2 housekeeping control genes, the relative expression of each gene was corrected using the geometric average of both genes. Data are reported as the gene expression ratio between 2 groups (means $\pm \mathrm{SD}$ ).

\section{RESULTS}

The evaluation of the gene expression pattern over time in resistant animals showed 
that none of the 6 genes showed altered expression $24 \mathrm{~h}$ after infestation (Figure 1). At 48 $\mathrm{h}$ after infestation, the genes for IL10, FoxP3, CD25, and CXCL10 were found to be overexpressed when compared to 0 -h levels. The genes for CXCL8 and TNF- $\alpha$ showed no expression changes over time in the resistant group.

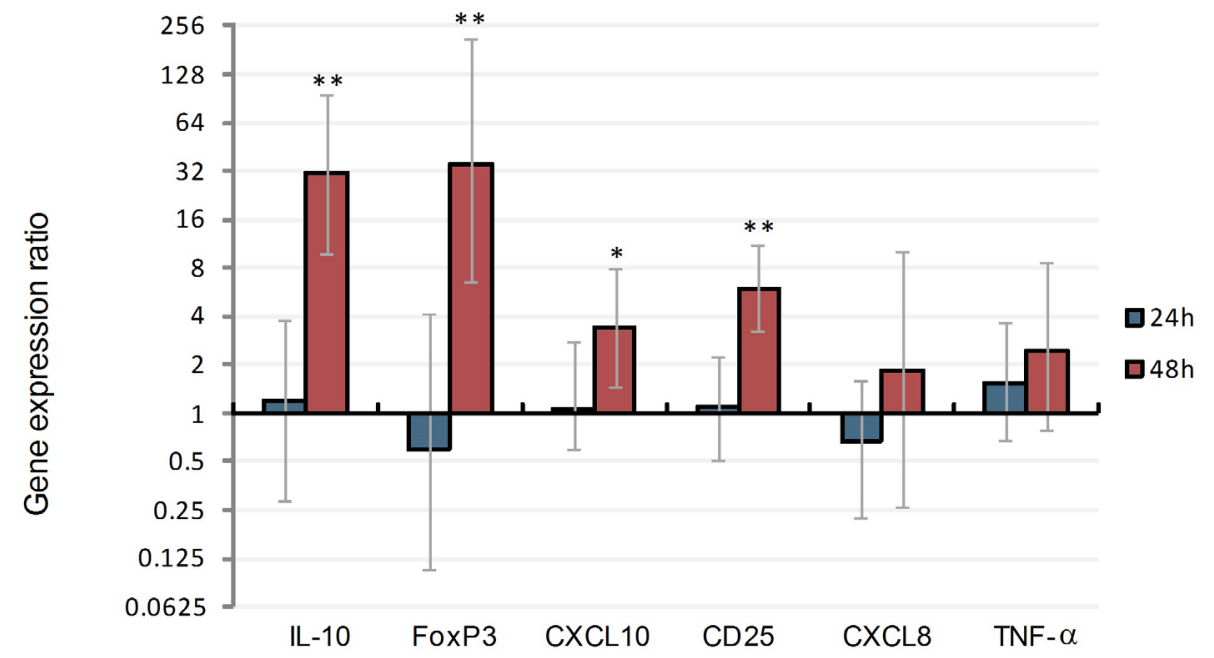

Figure 1. Gene expression ratio after artificial infestation ( 24 and $48 \mathrm{~h}$ ) compared to $0 \mathrm{~h}$ (before infestation) in tick resistant animals. $* \mathrm{P}<0.05 ; * * \mathrm{P}<0.01$.

In susceptible animals, CXCL8 and CXCL10 showed changes in gene expression pattern over time (Figure 2). CXCL10 showed higher expression $24 \mathrm{~h}$ after infestation when compared to $48 \mathrm{~h}$. CXCL8 was expressed at a lower level 24 and $48 \mathrm{~h}$ after infestation compared to the level observed at $0 \mathrm{~h}$.

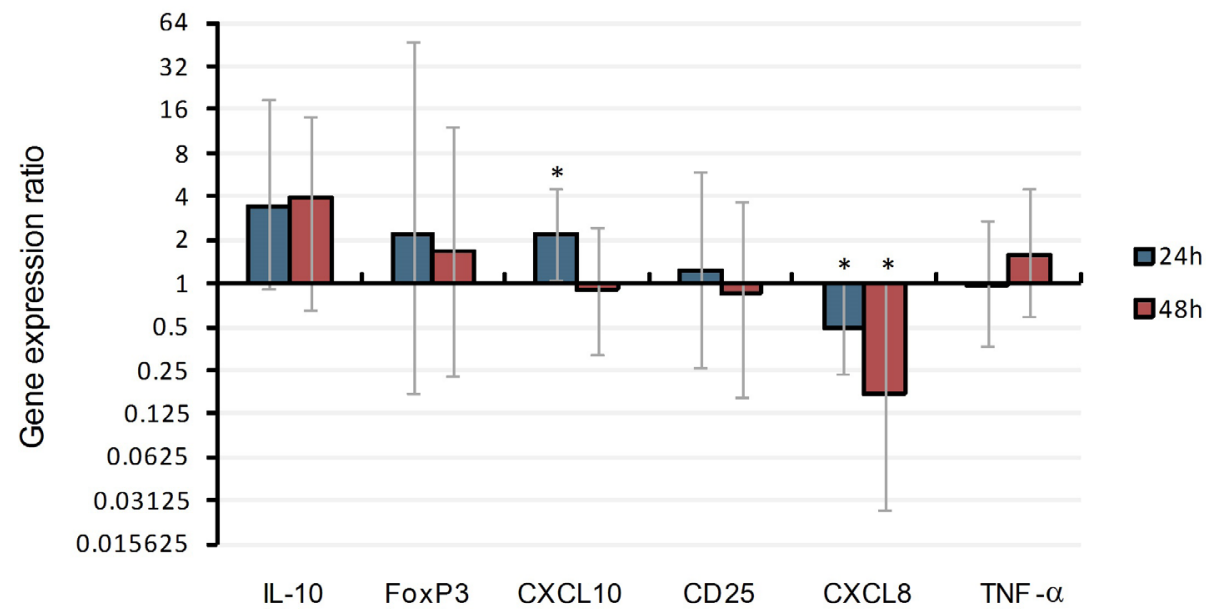

Figure 2. Gene expression ratio after artificial infestation ( 24 and $48 \mathrm{~h}$ ) compared to $0 \mathrm{~h}$ (before infestation) in tick susceptible animals. ${ }^{*} \mathrm{P}<0.05$. 
The comparison of the resistant:susceptible gene expression ratio regarding the time after infestation showed that CXCL8 was more highly expressed at 0 and $24 \mathrm{~h}$ after infestation. The IL-10, FoxP3, and CXCL8 genes showed an increased expression ratio $24 \mathrm{~h}$ after infestation. The FoxP3, CXCL10, and CD25 genes showed a decreased expression ratio $48 \mathrm{~h}$ after infestation (Figure 3).

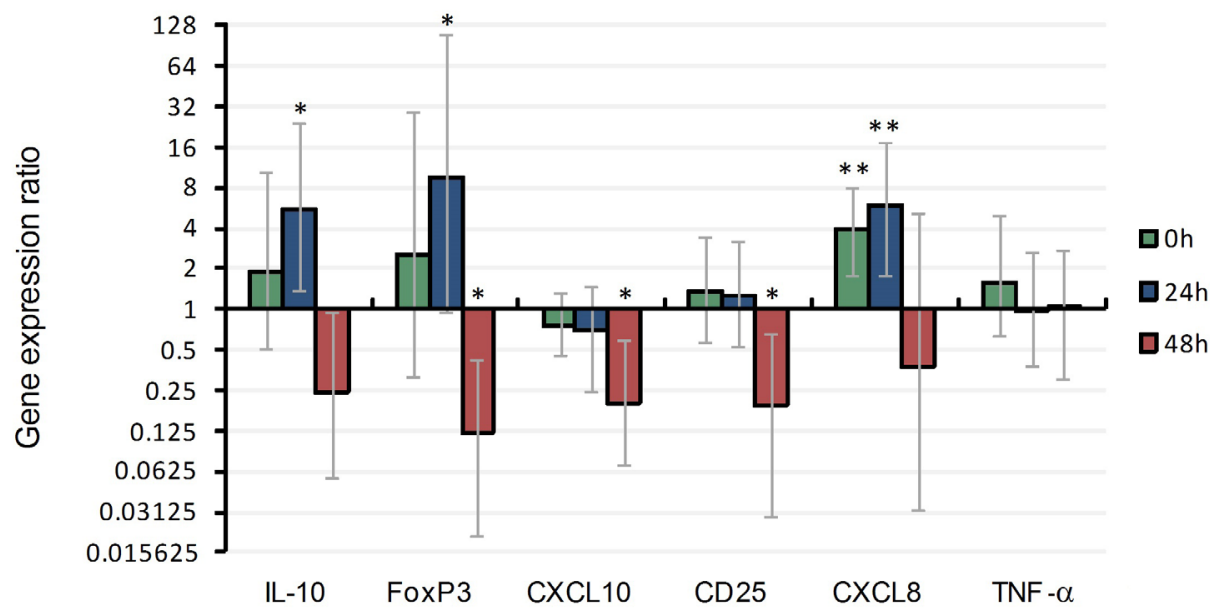

Figure 3. Resistant:susceptible gene expression rate at 0,24 and $48 \mathrm{~h}$ after tick infestation. $* \mathrm{P}<0.05 ; * * \mathrm{P}<0.01$.

\section{DISCUSSION}

This is the first study to evaluate gene expression in the peripheral blood of crossbreed cattle showing contrasting phenotypes of tick resistance in order to infer the immunological response to $R$. microplus infestation. The high variation in gene expression, observed at error bars (Figures 1,2 and 3) could be due to the origin experimental animals. F2 animals are more variable in their traits than pure breed animals.

The CD25 gene is known to be expressed in activated cells, including T cells, B cells, monocytes, and regulatory T cells (Belkaid, 2007). Higher expression of this gene in resistant animals suggests the presence of more $\mathrm{CD} 25^{+}$-marked cells in the animal's blood $48 \mathrm{~h}$ after infestation. Piper et al. (2009) also observed higher expression of CD25 in the blood of resistant Brahman heifers after tick infestation. Constantinoiu et al. (2010) found that after successive tick infestations in Brahman animals, a higher amount of $\mathrm{CD} 25^{+}$cells was observed in the skin of resistant animals. However, they were not able to identify the particular cellular phenotype presenting this surface marker that was responsible for such variation. One type of cell that presents this surface marker is the $\mathrm{T} \gamma \delta$ cell. Piper et al. (2009) found a larger amount of $\mathrm{T} \gamma \delta$ cells in the blood of resistant animals compared to susceptible animals. In addition, in evaluating skin biopsies, Constantinoiu et al. (2010) also observed a higher proportion of this cellular phenotype in resistant animals. This increase in activated $\mathrm{T} \gamma \delta$ cell number may be responsible for the observe increase in the $\mathrm{CD} 25^{+}$cell number, a marker for activated T cells, which was also found in the resistant animals. 
Bovine $T \gamma \delta$ cells show innate and acquired immunity characteristics and can perform regulatory functions in the immune system (reviewed by Guzman et al., 2012). Constantinoiu et al. (2010) found a decrease in the amount of CD25-marked cells over time after successive infestations, suggesting that this was related to the action of regulatory T cells. Typically, such cells express the intracellular transcription factor FOXP3 and play a role in immune response suppression and the control of homeostasis through IL-10, among other cytokines (Zheng et al., 2004). However, in bovine, monocytes and $\mathrm{T} \gamma \delta$ cells play a regulatory function in the response through the expression of IL-10 (Hoek et al., 2009) and not the $\mathrm{CD} 4{ }^{+} \mathrm{CD} 25^{\text {high }} \mathrm{Foxp} 3^{+}$ cells, as has been observed in humans (Hori et al., 2003).

In the current study, to assess the regulatory action of $\mathrm{T} \gamma \delta$ cells, differential expression of IL-10 was evaluated in the blood of experimental animals. Interestingly, the expression pattern of CD25 was the same as that of IL-10 (Figure 1), suggesting that resistant animals show higher activity of $\mathrm{T} \gamma \delta$ cells, which play a regulatory role in the immune response.

An important chemokine for $\mathrm{T} \gamma \delta$ cell transport is CXCL10, the major ligand of the receptor CXCR3, which is present in large amounts in $\mathrm{T} \gamma \delta$ cells of the human circulating subset (Poggi et al., 2007). The high expression of this chemokine in the blood of resistant animals observed in this study suggests a broad distribution of this cell type in these animals.

Interestingly, we observed altered expression of the FOXP3 gene, which followed a very similar pattern to that observed for IL-10. Hoek et al. (2009) found that in bovine, $\mathrm{CD} 4{ }^{+} \mathrm{CD} 25^{\text {high }} \mathrm{FoxP} 3{ }^{+}$cells are not anergic, suggesting that multiplication of this cellular phenotype occurs in resistant bovines. Although previously described in bovines, the function of this phenotype is not known, and new assays are needed to define which interleukins are produced by the FOXP3+ cells in bovine, as well as their biological function, in order to determine the relationship between such actions and tick infestation.

Piper et al. (2009) found a higher population of $\mathrm{CD} 14^{+}$cells (cellular marker of granulocytes, primarily neutrophils) in the blood of susceptible animals $24 \mathrm{~h}$ after infestation. In our study, interleukin 8 (CXCL8) transcripts, which are responsible for neutrophil attraction and activation, showed higher expression in susceptible animals at 0 and $24 \mathrm{~h}$ after infestation when compared to resistant animals. Higher expression of this chemokine indicates that susceptible animals are responding to previous tick infestations.

We also observed that CXCL8 expression was reduced after tick infestation in susceptible animals only, but became similar to that of resistant animals $48 \mathrm{~h}$ after infestation. Wang et al. (2007) evaluated B. taurus animals and observed decreased CXCL8 expression in the skin of susceptible animals after infestation. Hajnická et al. (2001) demonstrated antiCXCL8 action in the salivary gland extract (SGE) of several tick species. This CXCL8 blockage confers a survival advantage to the tick (Brossard and Wikel, 2004), and such blockage may be better controlled in resistant animals. Another explanation for the decreased CXCL8 expression observed in the peripheral blood of susceptible animals is the tendency of infiltration of the cells attracted by this chemokine to the site of the tick fixation. Constantinoiu et al. (2010) observed massive granulocyte infiltration (most likely neutrophils) into the skin tissue of susceptible animals.

According to a review by Brossard and Wikel (2004), the saliva of several tick species can inhibit expression of $\mathrm{TNF} \alpha$, among others cytokines. In our study, alterations in the expression of TNF $\alpha$ in the blood were not observed, which suggests that this proinflammatory cytokine was not important for the immune response in this infestation. 
Our results suggest a relationship between $\mathrm{T} \gamma \delta$ cell activity, detected by measuring gene expression, and the immunological mechanisms that result in higher resistance to $R$. microplus in cattle. Additional studies examining gene expression and characterizing the cell population in the peripheral blood are necessary to understand bovine resistance to the bovine tick.

\section{ACKNOWLEDGMENTS}

We thank FAPEMIG and CNPq for financial support and Embrapa Dairy Cattle for financial and technical support. R. Domingues received a graduate scholarship from CNPq, Brazil.

\section{REFERENCES}

Alvinerie M, Sutra JF, Galtier P and Mage C (1999). Pharmacokinetics of eprinomectin in plasma and milk following topical administration to lactating dairy cattle. Res. Vet. Sci. 67: 229-232.

Bagnall N, Gough J, Cadogan L, Burns B, et al. (2009). Expression of intracellular calcium signalling genes in cattle skin during tick infestation. Parasite Immunol. 31: 177-187.

Belkaid Y (2007). Regulatory T cells and infection: a dangerous necessity. Nat. Rev. Immunol. 7: 875-888.

Brossard M and Wikel SK (2004). Tick immunobiology. Parasitology (Suppl 129): S161-S176.

Constantinoiu CC, Jackson LA, Jorgensen WK, Lew-Tabor AE, et al. (2010). Local immune response against larvae of Rhipicephalus (Boophilus) microplus in Bos taurus indicus and Bos taurus taurus cattle. Int. J. Parasitol. 40: 865-875.

George JE, Pound JM and Davey RB (2004). Chemical control of ticks on cattle and the resistance of these parasites to acaricides. Parasitology (Suppl 129): S353-S366.

Guzman E, Price S, Poulsom H and Hope J (2012). Bovine $\gamma \delta$ T cells: cells with multiple functions and important roles in immunity. Vet. Immunol. Immunopathol. 148: 161-167.

Hajnická V, Kocáková P, Sláviková M, Slovák M, et al. (2001). Anti-interleukin-8 activity of tick salivary gland extracts. Parasite Immunol. 23: 483-489.

Hoek A, Rutten VP, Kool J, Arkesteijn GJ, et al. (2009). Subpopulations of bovine WC1(+) gammadelta T cells rather than CD4(+)CD25(high) Foxp3(+) T cells act as immune regulatory cells ex vivo. Vet. Res. 40: 6.

Hori S, Nomura T and Sakaguchi S (2003). Control of regulatory T cell development by the transcription factor Foxp3. Science 299: 1057-1061.

Jonsson NN (2006). The productivity effects of cattle tick (Boophilus microplus) infestation on cattle, with particular reference to Bos indicus cattle and their crosses. Vet. Parasitol. 137: 1-10.

Kongsuwan K, Piper EK, Bagnall NH, Ryan K, et al. (2008). Identification of genes involved with tick infestation in Bos taurus and Bos indicus. Dev. Biol. 132: 77-88.

Leite RC, Labruna MB, Oliveira PR, Monteiro AMF, et al. (1995). In vitro susceptibility of engorged females from different populations of Boophilus microplus to commercial acaricides. Rev. Bras. Parasitol. Vet. 4: 283-294.

Leutenegger CM, Alluwaimi AM, Smith WL, Perani L, et al. (2000). Quantification of bovine cytokine mRNA in milk cells of healthy cattle by real-time Taq Man polymerase chain reaction. Vet. Immunol. Immunopathol. 77: 275-287.

Machado MA, Azevedo AL, Teodoro RL, Pires MA, et al. (2010). Genome wide scan for quantitative trait loci affecting tick resistance in cattle (Bos taurus x Bos indicus). BMC Genomics 11: 280.

Nascimento CS, Machado MA, Guimaraes SE, Guimaraes MF, et al. (2010). Differential expression of genes in resistant versus susceptible Gyr x Holstein cattle challenged with the tick Rhipicephalus (Boophilus) microplus. Genet. Mol. Res. 9: 1974-1979.

Pfaffl MW, Horgan GW and Dempfle L (2002). Relative expression software tool (REST) for group-wise comparison and statistical analysis of relative expression results in real-time PCR. Nucleic Acids Res. 30: e36.

Piper EK, Jackson LA, Bagnall NH, Kongsuwan KK, et al. (2008). Gene expression in the skin of Bos taurus and Bos indicus cattle infested with the cattle tick, Rhipicephalus (Boophilus) microplus. Vet. Immunol. Immunopathol. 126: 110-119.

Piper EK, Jonsson NN, Gondro C, Lew-Tabor AE, et al. (2009). Immunological profiles of Bos taurus and Bos indicus cattle infested with the cattle tick, Rhipicephalus (Boophilus) microplus. Clin. Vaccine Immunol. 16: 1074-1086.

Piper EK, Jackson LA, Bielefeldt-Ohmann H, Gondro C, et al. (2010). Tick-susceptible Bos taurus cattle display an increased cellular response at the site of larval Rhipicephalus (Boophilus) microplus attachment, compared with tickresistant Bos indicus cattle. Int. J. Parasitol. 40: 431-441. 
Poggi A, Zancolli M, Catellani S, Borsellino G, et al. (2007). Migratory pathways of gammadelta T cells and response to CXCR3 and CXCR4 ligands: adhesion molecules involved and implications for multiple sclerosis pathogenesis. Ann. N. Y. Acad. Sci. 1107: 68-78.

Reck J, Jr., Berger M, Terra RM, Marks FS, et al. (2009). Systemic alterations of bovine hemostasis due to Rhipicephalus (Boophilus) microplus infestation. Res. Vet. Sci. 86: 56-62.

Regitano LCA and Prayaga K (2010). Ticks and Tick-Borne Diseases in Cattle. In: Breeding for Disease Resistance in Farm Animals 3rd edn (Bishop S, ed.). CABI, Midlothian, 295-314.

Samish M (2000). Biocontrol of ticks. Ann. N. Y. Acad. Sci. 916: 172-178.

Seo KS, Lee SU, Park YH, Davis WC, et al. (2007). Long-term staphylococcal enterotoxin C1 exposure induces soluble factor-mediated immunosuppression by lovine $\mathrm{CD}^{+}$and $\mathrm{CD}^{+} \mathrm{T}$ cells. Infect. Immun. 75: 260-269.

Seifert GW (1971). Variations between and within breeds of cattle in resistance to field infestations of the cattle tick (Boophilus microplus). Aust. J. Agri. Res. 22: 159-168.

Sonenshine DE, Kocan KM and de la Fuente J (2006). Tick control: further thoughts on a research agenda. Trends Parasitol. 22: 550-551.

Tao W, Mallard B, Karrow N and Bridle B (2004). Construction and application of a bovine immune-endocrine cDNA microarray. Vet. Immunol. Immunopathol. 101: 1-17.

Wagland BM (1978). Host resistance to cattle tick (Boophilus microplus) in Brahman (Bos indicus) cattle. III. Growth on previously unexposed animal. Aust. J. Agri. Res. 29: 401-409.

Wang YH, Reverter A, Kemp D, Mcwilliam SM, et al. (2007). Gene expression profiling of Hereford Shorthorn cattle following challenge with Boophilus microplus tick larvae. Aust. J. Exp. Agri. 47: 1397-1407.

Zheng SG, Wang JH, Gray JD, Soucier H, et al. (2004). Natural and induced CD4 ${ }^{+} \mathrm{CD} 25^{+}$cells educate CD4+. J. Immunol. 172: 5213-5221. 